\title{
Biological Factors Linking ApoE $\varepsilon 4$ Variant and Severe COVID-19
}

\author{
Jameel Inal ${ }^{1,2}$ (D) \\ Accepted: 17 September 2020 / Published online: 2 October 2020 \\ (C) Springer Science+Business Media, LLC, part of Springer Nature 2020
}

\section{Dear Editor,}

The recent review by Moriarty et al. [1] provided a very pertinent analysis of the increased risks from thromboses and other cardiovascular complications of patients with elevated levels of lipoprotein(a) ( $\mathrm{Lp}(\mathrm{a})$ ) following coronavirus disease 2019 (COVID-19). This included an erudite analysis of raised levels of $L p(a)$ in certain ethnic groups and association with higher frequency of ApoE4 genotypes and risk of severe COVID-19. Whilst this raises the question as to whether ApoE4 genotypes may affect COVID-19 prognosis, recent data is helping to address this issue.

Analysis of data from 382,188 participants of the European ancestry in the UK Biobank [2] revealed a high risk of severe COVID-19, in the $2.36 \%(n=9022)$ of people carrying two copies of the faulty gene variant of ApoE $\varepsilon 4$, with $5.13 \%$ ( $n=$ 37) of the COVID-19-positive participants after hospitalization carrying this gene variant. Compared with the more common ApoE $\varepsilon 3 \varepsilon 3$ genotype, the risk of severe COVID-19 for people carrying two ApoE $\varepsilon 4$ alleles was doubled (OR = 2.31), including people who had neither developed Alzheimer's disease (AD) (as for the 5.13\% COVID-19positive participants) nor cardiovascular disease (CVD), and for whom two copies of $A p o E \varepsilon 4$ also carried increased risk.

Besides raised $\mathrm{Lp}(\mathrm{a})$, as highlighted by Moriarty et al., other biological effects may link the $A p o E \varepsilon 4 \varepsilon 4$ genotype to severe COVID-19. To explore this, the role of ApoE $\varepsilon 4 \varepsilon 4$ in possible risk factors of venous thromboembolism-related mortality, such as extracellular vesicle (EV) release/altered content, von Willebrand factor (vWF) as well as angiotensinconverting enzyme 2 (ACE2), must be considered.

Jameel Inal

j.inal@londonmet.ac.uk

1 Cellular and Molecular Immunology Research Centre, School of Human Sciences, London Metropolitan University, London, UK

2 Biosciences Research Group, School of Life and Medical Sciences, University of Hertfordshire, Hatfield, UK

\section{EV Biogenesis Linking ApoE \&4 Variant to COVID-19}

Curiously, studying the effect of the ApoE $\varepsilon 4$ variant on EV biogenesis in the brain may help us understand the illusive 'biological mechanism' linking it to COVID-19. Analysing human post-mortem tissue and tissue from $A p o E$ \& 4 mice (expressing human ApoE4), the $A p o E \varepsilon 4$ genotype reduced local EV production but, more importantly in terms of EVs' role in VTE, altered lipid composition [3]. Relative to total brain, EV cholesterol levels were $10 \times$ and $50 \times$ greater for ceramide and ganglioside, respectively. Lipoproteins from conditioned media of human ApoE4-expressing mouse astrocytes, relative to ApoE3, increased phosphatidylserine (PtdSer) synthesis. If this increase occurred in EVs, where PtdSer is expressed on the outer leaflet of the lipid bilayer, which from blood and vascular cells contributes to thrombotic events, they would be more procoagulant, in a tissue factor-(TF-) independent manner.

\section{vWF Linking ApoE ع4 Variant to COVID-19}

Besides $\mathrm{AD}$, the $A p o E \varepsilon 4$ allele, as a major genetic risk factor for CVD and stroke, will also affect the vascular system. Upon infection with severe acute respiratory syndrome-coronavirus2 (SARS-CoV-2), the hyperinflammatory response and consequent endothelial dysfunction initiate a local procoagulant environment as suggested by the pulmonary microthrombi observed in COVID-19. Significantly raised vWF [4] released by TNF- $\alpha$ and IL- $1 \beta$ activation of endothelial cells (ECs) is just one feature of the ensuing coagulopathy. Using humaninduced pluripotent stem cell-derived ECs harbouring ApoE $\varepsilon 4 \varepsilon 4$, endothelial dysfunction has previously been manifest by increased platelet binding and increased expression of vWF, promoting a prothrombotic condition [5]. 


\section{ACE2 and a Possible Link Between ApoE $\varepsilon 4$ Allele and COVID-19}

Demonstration of $\varepsilon 4$ as a risk allele in $\mathrm{AD}$ is pertinent to $\varepsilon 4$ being a risk allele in severe COVID-19, because ACE2 (receptor for SARS-CoV-2) is reduced in individuals that are carriers of $A p o E$ \& 4 [6]. As an indirect measure for reduced ACE2 activity, the level of Ang II, which ACE2 converts to the vasodilatory peptide $\operatorname{Ang}(1-7)$, was increased, as is found in COVID-19 patients where Ang II levels are twice normal [7]. Ang II is a powerful vasoconstrictor. Through reactive oxygen species such as superoxide $\left(\mathrm{O} 2^{\circ-}\right)$ and hydroxyl $\left(\mathrm{OH}^{-}\right)$, it decreases nitric oxide bioavailability, causes EC dysfunction and promotes a prothrombotic milieu leading to VTE.

\section{Concluding Remarks}

In continuing to explore the possible association of the ApoE $\varepsilon 4$ allele with COVID-19, it is useful to remember that $A p o E$ is also linked to susceptibility to infection by viruses [8] (as well as bacteria and parasites, including secondary infection), for example, ApoE4 increasing HIV-1 infection, two copies of $\varepsilon 4$ aiding accelerated disease development [8]. If the ApoE $\varepsilon 4$ allele indeed influences COVID-19 severity, this may explain the prevalence of severe disease amongst certain ethnicities, as in one study the allele frequency was $29.5 \%$ for AA versus $12.1 \%$ for the Caucasian group [9]. Furthermore, up to midApril 2020, 34\% of deaths from COVID-19 in the USA occurred amongst AAs, despite the population representing only $13 \%$ of all Americans [10]. In conclusion, ApoE $\varepsilon 4$ may have multifaceted effects in COVID-19 which may also be reflected in ethnicity.

\section{References}

1. Moriarty PM, Gorby LK, Stroes ES, Kastelein JP, Davidson M, Tsimikas S. Lipoprotein(a) and its potential association with thrombosis and inflammation in COVID-19: a testable hypothesis. Curr Atheroscler Rep. 2020;22(9):48.

2. Kuo CL, Pilling LC, Atkins JL, et al. APOE e4 genotype predicts severe COVID-19 in the UK Biobank community cohort. J Gerontol A Biol Sci Med Sci. 2020.

3. Peng KY, Pérez-González R, Alldred MJ, Goulbourne CN, Morales-Corraliza J, Saito M, et al. Apolipoprotein E4 genotype compromises brain exosome production. Brain J Neurol. 2019;142(1):163-75.

4. Zachariah U, Nair SC, Goel A, Balasubramanian KA, Mackie I, Elias E, et al. Targeting raised von Willebrand factor levels and macrophage activation in severe COVID-19: consider low volume plasma exchange and low dose steroid. Thromb Res. 2020;192:2.

5. Rieker C, Migliavacca E, Vaucher A, et al. Apolipoprotein E4 expression causes gain of toxic function in isogenic human induced pluripotent stem cell-derived endothelial cells. Arterioscler Thromb Vasc Biol. 2019;39(9):e195-207.

6. Kehoe PG, Wong S, Al Mulhim N, Palmer LE, Miners JS. Angiotensin-converting enzyme 2 is reduced in Alzheimer's disease in association with increasing amyloid- $\beta$ and tau pathology. Alzheimers Res Ther. 2016;8(1):50.

7. Liu Y, Yang Y, Zhang C, Huang F, Wang F, Yuan J, et al. Clinical and biochemical indexes from 2019-nCoV infected patients linked to viral loads and lung injury. Sci China Life Sci. 2020;63(3):364 74.

8. Burt TD, Agan BK, Marconi VC, He W, Kulkarni H, Mold JE, et al. Apolipoprotein (apo) E4 enhances HIV-1 cell entry in vitro, and the APOE epsilon4/epsilon4 genotype accelerates HIV disease progression. Proc Natl Acad Sci U S A. 2008;105(25):8718-23.

9. Borenstein AR, Mortimer JA, Wu Y, Jureidini-Webb FM, Fallin $\mathrm{MD}$, Small BJ, et al. Apolipoprotein $\mathrm{E}$ and cognition in community-based samples of African Americans and Caucasians. Ethn Dis. 2006;16(1):9-15.

10. Holmes L, Jr., Enwere M, Williams J, et al: Black-white risk differentials in COVID-19 (SARS-COV2) transmission, mortality and case fatality in the United States: translational epidemiologic perspective and challenges. Int J Environ Res Public Health 2020, $17(12)$.

Publisher's Note Springer Nature remains neutral with regard to jurisdictional claims in published maps and institutional affiliations. 